\title{
The status of maintenance management in Swedish manufacturing firms
}

\author{
Patrik Jonsson \\ Department of M anagement and Economics, Växjö University, \\ Växjö, Sweden
}

\section{Introduction}

Maintenance has become more important since firms have downsized their organizations, minimized inventory levels and changed to flexible and timebased manufacturing systems. Flexibility is no longer built into the system and reactive maintenance policies have to be exchanged for proactive policies integrated in production. The aim of maintenance is to support and maintain efficient production. It can no longer be considered a cost centre separated from the main business processes of firms, but an integrated function, linked to production and manufacturing strategy. The impact of maintenance on quality and unit costs has to be understood. A dvantages could probably be gained by co-ordinating maintenance goal setting with manufacturing and corporate strategies, improving the status of maintenance and integrating it with the overall information system. The trends in maintenance are towards simple maintenance by operators, on-condition maintenance, outsourcing of heavy maintenance and decreasing plant assets. A Il these separate trends are towards more effective maintenance, but they are often not fully developed or implemented in most firms.

The main objectives of this paper are to present a framework for describing maintenance management and to analyse its status in Swedish manufacturing firms. The status of maintenance management is studied through a survey, designed with the developed framework as a comparative datum.

\section{Methodology}

Sample

The sample consists of companies in the food, timber, paper, chemical, mechanical engineering and iron industry, chosen to cover companies with different manufacturing environments and processes (see Table I). M ost measures in the survey instrument had not been used in any previous study. The survey instrument was pretested and sent by mail to 747 maintenance managers or production managers of Swedish manufacturing firms, with more than 50 employees. The respondents were asked about their maintenance strategy, perceived status of maintenance in their organization, commitment to and participation in maintenance activities, the characteristics of their

Journal of Quality in Maintenance Engineering, Vol. 3 N o. 4, 1997 pp. 233-258. ( ) M CB University Press, 1355-2511 


\begin{tabular}{|c|c|c|c|c|c|c|c|}
\hline $\begin{array}{l}\text { JQME } \\
3,4\end{array}$ & & $\begin{array}{l}\text { Number } \\
\text { sent }\end{array}$ & $\begin{array}{c}\text { Total } \\
\text { number of } \\
\text { responses }\end{array}$ & $50-100$ & $\begin{array}{c}\text { Size } \\
101-500\end{array}$ & $>500$ & $\begin{array}{c}\text { Total response } \\
\text { rate }(\%)\end{array}$ \\
\hline \multirow{3}{*}{234} & Food & 74 & 31 & 11 & 14 & 6 & 42 \\
\hline & Timber & 48 & 24 & 15 & 9 & 0 & 50 \\
\hline & Paper/print & 121 & 46 & 11 & 25 & 10 & 38 \\
\hline \multirow{4}{*}{$\begin{array}{l}\text { Table I. } \\
\text { Data about respondents }\end{array}$} & Chemical & 114 & 43 & 23 & 18 & 2 & 38 \\
\hline & $\begin{array}{l}\text { M echanical } \\
\text { engineering }\end{array}$ & 366 & 131 & 63 & 53 & 15 & 36 \\
\hline & Iron/steel & 24 & 9 & 4 & 5 & 0 & 38 \\
\hline & Total & 747 & 284 & 127 & 124 & 33 & 38 \\
\hline
\end{tabular}

maintenance management information systems, how they spend maintenance time, which are the most important maintenance techniques, and how they organize maintenance resources. A nalyses of individual measures are presented in the sections discussing various maintenance components (goals and strategy, human aspects, support mechanisms, tools and techniques, organization). Other questions about maintenance, which will not be analysed in this paper, were also included in the questionnaire and it took the respondents about 15-20 minutes to fill in the questionnaire. The addresses were identified in the Sema Group database of Swedish organizations.

For this study, 284 relevant answers were received. There was a bias towards small and medium-sized mechanical engineering firms. More than 40 per cent of the responding firms belong to these two groups. However, this is a relevant proportion according to the proportion of such firms in the total population of Swedish manufacturing firms. The response rates of the various industries were almost the same. A comprehensive follow-up, in which 210 nonrespondents were telephoned, indicated faults in the database of addresses - 39 (or 19 per cent) of the 210 questionnaires had been addressed to irrelevant companies (that had no manufacturing function) and 46 had been addressed to incorrect people (but had been forwarded correctly). A nother 30 said they were not interested in answering. Forty telephone interviews were conducted. Chisquare tests indicated no significant difference between respondents and nonrespondents or between early and late answers regarding industry sectors and plant size $(p<0.05)$. If 19 per cent of the addresses are considered irrelevant, the total number of relevant companies would be 608 and the response rate 47 per cent. A response rate above 40 per cent is often considered necessary (Flynn et al., 1990), even though much recent empirical research in manufacturing shows lower response rates (e.g. Miller and Roth, 1994; Vickery et al., 1993)

Instrument and data analysis

The respondents from different industry sectors were grouped according to their size (number of employees). This resulted in a total of 18 groups of 
respondents (six industries and three sizes). However, most groups were too small to conduct statistical analysis. Therefore, statistical comparisons between small, medium and large firms (independent of industry sectors) and between the five largest industries (independent of size of firm) were carried out (see the A ppendix). The level of measurement differed between nominal, ordinal and interval scales.

The scales that measured "formulated maintenance strategy", "maintenance management information system" and "maintenance organization" were of a nominal type, and statistical comparisons were carried out through chi-square statistics. The overall values of chi-square were partitioned with the use of adjusted standardized residuals for each cell in the contingency tables. Proper application of the chi-square test requires that the expected frequencies in each cell are not too small. Cochran (1954) recommends that in tests for which the degrees of freedom are greater than 1, no more than 20 per cent of the cells have an expected frequency of less than 5 , and no cell have an expected frequency of less than 1. To obtain most of these requirements the categories "special" and "standard" were combined when analysing the maintenance information systems in the industries.

The scales for "perceived status", "commitment", "participation" and "techniques" were of an ordinal type with underlying continuous distributions. Kruskal-Wallis one-way analysis of variance by ranks was used for identification of overall differences across industries and sizes of firms, while Mann-W hitney tests were used for pairwise comparisons between individual industries and sizes.

Finally, the section on "planning, prevention and corrective maintenance" was measured with interval scales. The analyses were carried out through oneway A NOVA tests, and pairwise Scheffe's comparison. The results from the statistical tests are presented in the A ppendix. The original 18 groups were visually compared without any statistical method.

\section{A maintenance managment framework}

The concepts of total productive maintenance (TPM), terotechnology, reliability-centred maintenance (RCM), asset management, integrated logistics support (ILS) and life cycle cost/profit (LCC/LCP) focus on various topics of maintenance management. The TPM concept has succeeded very well in making maintenance into an overall company-wide issue, by focusing on continuous improvement, autonomous small group activities, training, education, communication and flow of information. The crucial factors are operator participation and that T QM has to be applied first. TPM does not, however, pay attention to any specific tool or technique for preventive maintenance (Nakajima, 1988). Terotechnology is a British concept focusing on the link between maintenance costs and feedback of proper information to designers and constructors, relying on maintenance optimization and life cycle costing (Husband, 1978). RCM is a systematic approach that differs from the two philosophies above. Firms could benefit from combining the RCM method
The status of maintenance management 
JQME 3,4

with the TPM philosophy. RCM features a systematic road map for preventive maintenance in complex plants, like the airline industry. The fundamental principle of RCM is that scheduled maintenance has little effect on the overall reliability of a complex item, unless the item has a dominant wear out failure (Smith, 1993). RCM almost ignores cost. It does not recognize maintenance as a fundamentally economic problem, but tries to achieve the "inherent reliability" of the system. A sset management takes a company-wide life-cycle approach to equipment but, unlike TPM, it focuses on economic and financial issues, and not engineering (Pintelon and Gelders, 1992; Young, 1996). Terotechnology, on the other hand, tries to combine both issues. LCC/LCP focuses on external effectiveness and how maintenance can contribute to improved revenues (A hImann, 1984). ILS is the A merican counterpart to these life-cycle concepts, with a greater emphasis on logistics (Blanchard, 1991).

The differences and borderlines between these maintenance concepts are vague and vary between authors and users. The importance of viewing maintenance as a company-wide approach is obvious. A few integrated maintenance management approaches, besides the above-mentioned "concepts", have been presented (e.g. Ben-Daya and Duffuaa, 1995; Geraerds, 1991; Kelly, 1989; Pintelon, 1990; Pintelon and Gelders, 1992; Raouf and BenDaya, 1995; Yamashina, 1995), but no uniform maintenance management model yet exists.

To describe the status of maintenance in various firms we felt it necessary to have a uniform maintenance management framework. The framework consists of five linked components;

- goals and strategy;

- human aspects;

- support mechanisms;

- tools and techniques;

- organization.

The first component is about goals and strategies that lead the organization to fulfil corporate objectives. Human aspects constitute the second factor which is the basis for company-wide commitment and continuous improvement. The third element is supporting mechanisms, such as information systems, that make the communication and spread of information easier. The fourth component is maintenance tools and techniques, and the fifth the organization structure that determines resources. The effectiveness of the maintenance management policy depends a lot on the strength of the links between these components as well as on their individual effectiveness.

\section{Goals and strategy}

Maintenance goals and strategies constitute one of the most important components of the maintenance management framework. They should be formulated to support the corporate strategy and business drivers that 
constitute the critical success factors of the firm. M aintenance management will for example, support corporate strategies striving towards least-cost producers, reliability of supply or high product quality.

Strategies for maintenance act as co-ordinating and integrating mechanisms, if they are related to corporate and production strategies, maintenance knowledge, and committed to by the management as well as the personnel involved. Thirty years ago Skinner (1969) showed the necessity of integrating manufacturing into the corporate strategy, and that is still a problem in lots of firms. It is common that marketing and manufacturing groups decide on courses of action that are inconsistent with each other and the business strategy. Several authors (e.g. Buffa, 1984; Caron and Ernest, 1991) verify that manufacturing strategies have been left out in the past, which has led to strategies with production "out of sync" because of a mismatch between the demands of the marketplace and the capability of the production system. The benefits of fully linking long-term corporate, marketing and manufacturing strategies and making plans jointly in an holistic approach cannot be underestimated. Tunälv (1992), for example, showed in an empirical study that companies with a manufacturing strategy derived from the corporate strategy and marketing plan emphasize quality programmes and other preventive actions to a higher extent and are more profitable than companies without such a manufacturing strategy. Hayes and Pisano (1994) consider that one of the key factors behind Japan's success is that Japanese companies have a clear, interlinked and holistic integration from marketing to manufacturing. The same should probably be true for maintenance strategies, given that manufacturing has already been successfully integrated. Clear goals should be expressed, at the equipment or system level, in operational and understandable terms - for example, "improve availability to 0.993 per cent", rather than "reduce maintenance costs by 10 per cent" (cf. Deming, 1986).

Many companies do not have clear goals for manufacturing and even fewer have any for maintenance. This is serious, as strategies and goals are prerequisites for achieving more effective maintenance. In the survey, the respondents were asked if they considered themselves to have a written, oral or no maintenance strategy at all. If they had a strategy, they were asked if it was integrated with the corporate strategy, integrated with the production but not the corporate strategy, or if it was separated from other strategies. Figure 1 shows the percentage of companies having no, oral and written maintenance strategies respectively. Only 48 per cent of the respondents were considered to

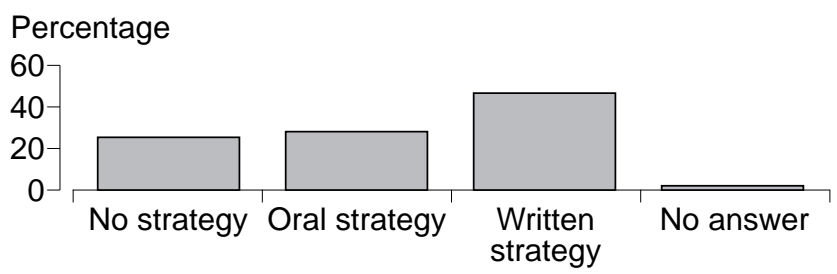

The status of maintenance management 
JQME 3,4

238

have a written maintenance strategy and 23 per cent had no strategy at all. M ore than two-thirds of those who had written strategies had derived them from manufacturing or corporate strategies. Chi-square tests identified significant diversion between industries, as well as between firms of various sizes. The timber industry had a lower proportion of written strategies than the average firm. Small firms, and especially small paper and mechanical firms, showed a higher incidence of no strategy (see the A ppendix). The proportion of firms having fully developed written maintenance strategies is probably actually lower than the 48 per cent reported, since some of the respondents considered ISO 9000 to be the written strategy and that is not necessarily enough.

It is not enough to formulate strategies, management commitment to the maintenance goals has to be present to make the integrated system work. A ttitude and communication problems between operations and maintenance are sometimes both prevalent and deep rooted and can be serious impediments to effective maintenance. Communication between maintenance and production supervisors and personnel is considered to be essential for successful maintenance (e.g. Bateman, 1995; Berger, 1993). One reason for management not giving enough attention to maintenance might be that they cannot see the connections between maintenance and profitability.

\section{Human aspects}

The human aspects and the importance of a learning organization have attracted more attention since the TQM concept has been accepted in organizations. The human aspects of a maintenance management system go hand in hand with those of T QM. Deming (1986) and other T QM-influenced papers (e.g. Kappelman and Prybutok, 1995; T ippett and Waits, 1994) asserted that the links between job fulfilment and continuous improvement, customer satisfaction and performance are very strong and that job satisfaction, job commitment and pride of workmanship are the most important factors in achieving employee fulfilment and empowerment. Similar findings have been found in the area of maintenance. Steudel and Desruelle (1992) for example asserted that the combination of involvement and training at all levels of the organization is the key to manufacturing and maintenance success. Thilander (1992) showed in case studies that competence, information and motivation were important prerequisites for effective maintenance, job satisfaction and overall productivity. She also found that lack of responsibility and commitment from foremen and senior managers caused a large part of the breakdowns. E ricsson and Dahlén (1993) showed that disruptions in the manufacturing system not only depend on technology, but also on work organization, labour stability and a set of external factors. Human aspects and failure of the system are consequently close connected. Malmholt (1990) for example, has confirmed Juran's well-known dictum, that human errors cause more than half of failures of a system and that up to 80 per cent of these require action by management. 
A basic condition for achieving a consensus for continuous improvement and job fulfilment in the area of maintenance is that the organization understands the importance of maintenance and that it enjoys good status. A favourable work environment without psychological or physical environmental problems is often argued to be one of two prerequisites, together with training/education, for TPM -like small group activities and continuous improvement (Nakajima, 1988). Lack of status can easily be an important obstacle to job fulfilment and empowerment. Hill (1990) highlighted a set of reasons for the lack of status of production/operations. T hese should be relevant for maintenance as well.

The respondents of the survey were asked about how they perceived the status of maintenance in their organization (on a scale from 1 to 6 , where 1 was very low status and 6 very high). Figure 2 shows that 32 per cent of the respondents considered that maintenance had low status in their organizations (below 4 on a scale from 1 to 6). The importance of maintenance to overall success has to be better understood in these firms, or they will probably fail to correct bad maintenance practices. The overall analysis indicated significant differences across industries and firms of various sizes, while pairwise tests revealed that the status of maintenance is significantly higher in food, paper and mechanical engineering firms than in the timber industry. It also showed that status is higher in large rather than in small and medium sized firms (see the A ppendix). No significant differences were found betw een the answers from maintenance managers and production managers.

It was highlighted above that management responsibility and commitment were important for effective maintenance. The respondents were asked to mark the production management's and direct production personnel's commitment to maintenance issues. They were also asked to what extent production management and direct production personnel participate in strategic maintenance planning. Six-point Likert scales were used. The latter question was only answered by the 77 per cent of firms that consider they have a maintenance strategy. Figure 3 shows that about one-fifth of the firms had production personnel with high commitment (on levels five to six). The relatively low proportion of firms with production personnel highly committed to maintenance issues indicates that Swedish firms have not fully made maintenance into a company-wide issue. Production management was committed to maintenance issues, on levels five or six, in about half of the firms

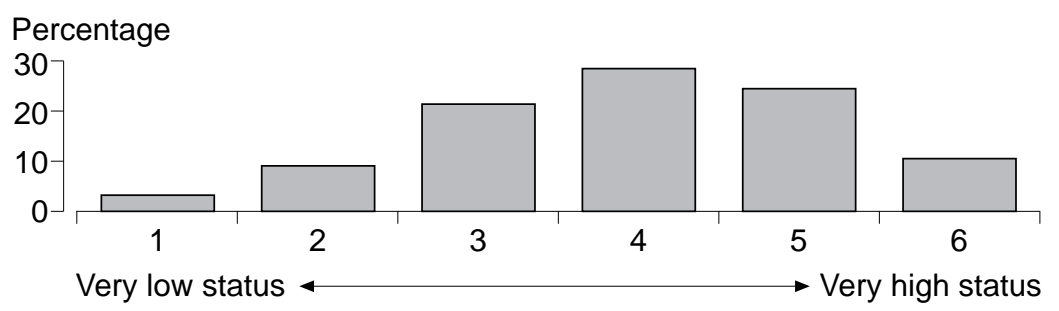

The status of maintenance management 
JQME 3,4

240

but, still 18 per cent of the firms considered that their production management was committed to maintenance on levels one to three.

Figure 4 shows that production management participated in the maintenance strategy formulation process, on levels five or six, in four-fifths of the firms. Only one-fifth of the firms have direct production personnel that participate on levels five or six. The high level of production management participation is considered a necessary condition for linking strategic manufacturing and maintenance planning. The lower proportion of firms with high level of commitment of production management and production personnel might lead to differences in intended and realized strategies. The analysis could not indicate any significant differences across industries or sizes of firms, regarding participation and commitment of production management or participation of production personnel. How ever, there was significant difference across industries regarding production personnel's commitment to maintenance issues. Pairwise tests revealed that the direct production personnel in the food and chemical industries were committed to maintenance issues at significantly lower levels than production personnel in the mechanical engineering industry (see A ppendix).

Figure 3.

Commitment to maintenance issues

F igure 4.

Participation in the maintenance strategy formulation process

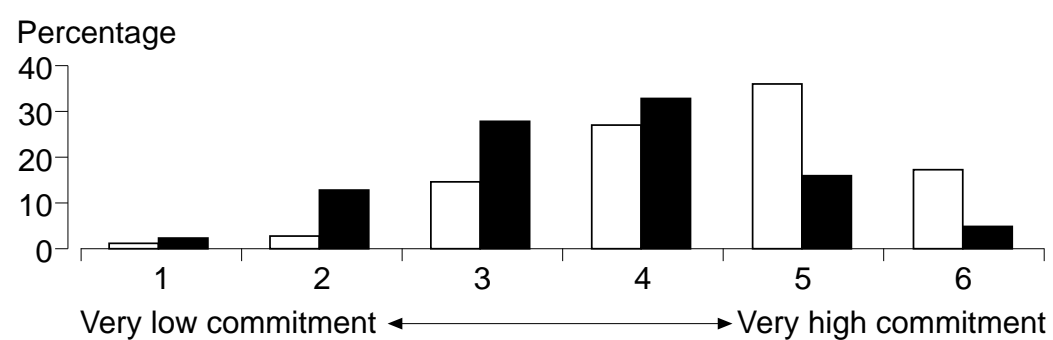

Key Production management Production personnel

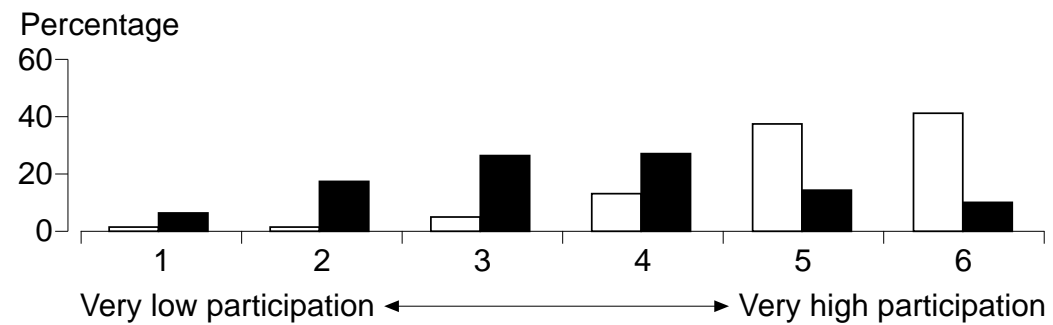

Key

Production management

Production personnel 


\section{Support mechanisms}

Support mechanisms make communication and information flow easier. The feedback control loop of maintenance data is necessary for lowering the life cycle costs at an early stage and implementing a Deming plan-do-check-actcycle (PDCA ) for continuous improvement.

The maintenance feedback system is not an internal affair of the maintenance or production department. Management should not marginalize the maintenance information system, but integrate it into the overall MIS. Spare-part provisioning and capital investment in new equipment rely on proper maintenance data. M ost of the life-cycle costs of equipment and products are determined at the design and prototyping stage (e.g. A hlmann, 1994; Smith and Knezevic, 1996), and are consequently easier to reduce at this stage than during full production. Purchasing and design functions have to consider these life cycle costs. The collection and feedback of accurate data are especially important; preventive maintenance optimization models depend on them, and equipment manufacturers and planners may be persuaded to act to improve their products. Preventative maintenance (PM) and lubrication schedules published by the machine manufacturer should rely on correct and up-to-date maintenance and availability data. Despite the importance of maintenance information, it is often forgotten in the management information systems (MIS) of organizations. Sherwin (1994) for example asserts that maintenance is the only vital part that is not yet properly integrated in the computer integrated manufacturing $(\mathrm{CIM})$ systems of organizations.

The survey shows that if a maintenance feedback system exists in firms it is seldom integrated with the overall management information system (MIS), but managed from a separate maintenance server. Respondents were asked about what kind of maintenance information system they used. They could choose between four alternatives; manual, custom-built maintenance system controlled from separate computer, standard system controlled from separate computer, or a system integrated into the overall MIS. Figure 5 shows that 64 per cent of the respondents relied on manual information systems and just 9 per cent had maintenance management information systems (M MIS) integrated into the MIS. Twenty-seven per cent managed M MIS from a separate computer. The integrated systems were mostly used by large firms, and especially large paper and chemical firms. Consequently, manual systems were significantly more common in small than in large firms (see the A ppendix). The interpretation of what comprises an integrated system varies between firms. Some of the

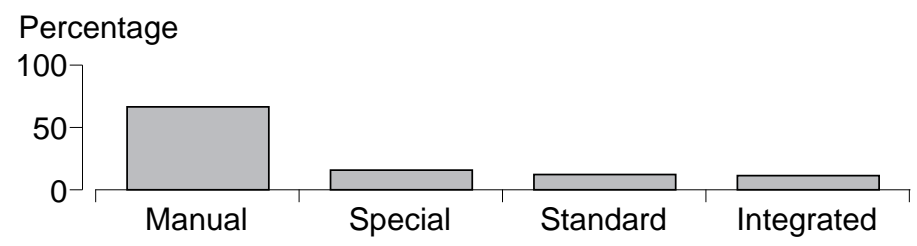

Figure 5. 
JQME 3,4

242

respondents who consider themselves to have an integrated system have probably not integrated it fully, e.g. are not using a mutual database, or planning PM and production together.

Benefits could be gained by integrating the maintenance information system into the overall MIS. The two systems are complementary rather than serial and the existence of the MIS should force the integration. Fully integrated computerized maintenance management systems can hardly be properly implemented until the other components of maintenance management are understood and implemented by the organization, but it plays an important role in overall maintenance management.

\section{Tools and techniques}

M aintenance tools and techniques consist of immediate and delayed corrective maintenance and scheduled and on-condition preventive maintenance. Lots of research shows that preventive techniques are not used as frequently as they should be. Corrective methods are more expensive than preventive ones, and Mobley (1990), for example, states that costs of repair performed in the corrective run-to-failure mode will average about three times higher than the same repair made within a preventive mode. Wireman (1990) estimated that only about 22 per cent of US firms are using preventive maintenance methods. Other studies conducted in the 1980s and 1990s (K ovach, 1983; Tombari, 1982; Tomlingson, 1993) show that the normal maintenance force operates at about 50 per cent capacity due to lack of maintenance planning and control and that an average of 60-70 per cent of maintenance time in US manufacturing firms is spent on emergencies. The conducted studies identify a trend towards more preventive maintenance, even if it is both slow and uncertain. The proportion of corrective maintenance could, as an average, be further decreased. Changes in the manufacturing environment force firms to focus on proactive techniques e.g. the exchange of stand-alone manufacturing for cellular manufacturing systems has decreased flexibility and further increased the need for preventive maintenance (Bateman, 1995).

Figure 6 illustrates how the maintenance time of the respondents of the present survey is shared between planning, prevention and correction. The respondents were asked how much of their maintenance time was spent on strategic planning, preventive maintenance, condition maintenance and corrective maintenance. T he answers were analysed in the three groups: strategic planning, preventive maintenance (preventive and on-condition maintenance) and corrective maintenance. The answers show that about half of

Figure 6.

Maintenance-related time

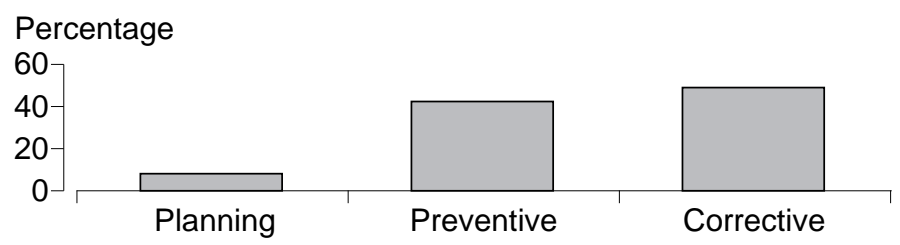


the maintenance time is spent on corrective actions and two-fifths on preventive or condition-based maintenance. The optimum figure for corrective maintenance is considered to not exceed 30-40 per cent (Tomlingson, 1993; Wireman, 1990) and most firms probably know this but are still not changing strategies or techniques. A n A NOVA indicated that there are significant differences across various sizes of firms. Pairwise tests revealed that small firms spend a significantly larger proportion of their maintenance time on strategic planning than large firms (see the A ppendix).

Planning of work load, overhaul, replacement, etc. are key activities in maintenance and are commonly discussed in the literature. There is an enormous number of models for planning maintenance activities and preventing failures in the literature and, in practice, there are proper models for most situations (e.g. Dekker, 1996). They are, how ever, not much used because of high complexity, lack of knowledge and data.

The solution for maintenance is not always just to increase planned preventive maintenance (PM). PM programmes are not always kept up to date, nor do they always work in harmony with production schedules. Proper data for calculating the schedules seldom exist and the proposed schedules often become somew hat arbitrary. A II machines are not average and improved preventive polices might lead to some machines being over-maintained and others under-maintained. This results in increased life cycle costs. Instead reliability-based on-condition maintenance should probably become more important for firms. It gives advance warning of impending problems and gives rise to maintenance activities. Condition-based maintenance has, together with decentralized maintenance inspection by operators, received much interest in the literature during the last few years.

Figure 7 does, how ever, show that condition monitoring has not achieved as much penetration as operator inspection in practice, probably because operators are still needed for tool changing and QC duties, and the cost of training them to keep watch for developing defects is marginal, whereas condition monitoring equipment is still more expensive. The respondents of the present study were asked to rank the most important and the second most important maintenance techniques of their companies. Every first ranked answer got two points and every second rank got one point. The two most important techniques were inspection at fixed intervals and corrective

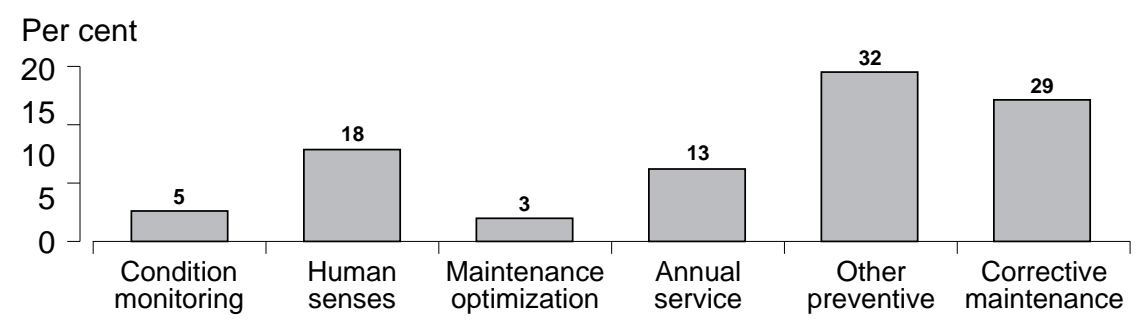

The status of maintenance management 
JQME 3,4

244 maintenance, followed by on-condition maintenance by human senses and annual service. Maintenance optimization by analysing reliability data and condition monitoring did not get very high priority. Data analysis indicated significant differences across different sizes of firm regarding condition monitoring and annual service. Pairwise tests revealed that large firms use condition monitoring techniques to a significantly higher extent than small and medium-sized firms, and use annual service to a significantly lower extent than small firms. Condition monitoring was the most important technique in large paper and chemical firms. A nnual service was most important in small mechanical engineering firms. Corrective maintenance was important in small and medium-sized enterprises and in the timber and iron industries. Condition monitoring and human senses were expected to be more important techniques (see the A ppendix).

\section{Organization}

The optimum maintenance organization structure is dependent on the specific conditions within the organization. Decentralization, participation of maintenance workers in project teams, focusing on the core business and outsourcing are common and important organizational trends. Transferring responsibility from maintenance workers to machine operators and a more holistic view result in faster response time when machines breakdown and an increased level of co-operation and trust between production/operations and maintenance workers. Kelly (1989) considered the most important factors for deciding about allocating maintenance resources to be plant layout and cost of plant availability. T hat was not analysed and this study could consequently not be verified.

By decentralizing maintenance activities, such as planning and supervision, to the operators, the costs and performance of maintenance can sometimes be improved. A study by Maggard and Rhyne, (1992) shows that 40 per cent of the traditional maintenance mechanic's work could be done by another employee, with minimal training, and another 40 per cent could be performed with additional training, but still below the certified level. Steudel and Desruelle (1992) argue that 80-90 per cent of the maintenance work should be carried out by the operators. A nother empirical study (Maggard and Rhyne, 1992) shows that 75 per cent of maintenance problems can be prevented by operators at an early stage, by frequent looking, listening, smelling and testing. How ever, these figures are case specific and are impossible to be used as generally optimum figures. Continuous training and education are necessary to fully decentralize maintenance to the operators.

The creation of strong strategic alliances, outsourcing maintenance and focusing on the core processes of firms have been more common and important lately. Trends towards more virtual organizations consisting of long supply chains competing in the marketplace, quality trends and internal suitability force companies to streamline their organizations and outsource parts of their support activities. A s the complexity of maintenance increases, due to improved 
mix of equipment and maintenance tools, it is more difficult to economically plan and co-ordinate and outsourcing may be the most appropriate form of allocation. In the more complex manufacturing environments, individuals have to specialize within their respective profiles and then the overall flexibility decreases. Flexibility can be improved by training or by co-operation with external maintenance suppliers. The benefits of outsourcing maintenance seems clear, but it still might be problematic to decide about the optimum type of contract (see Martin, 1997).

The respondents were asked how they organized the main part of their maintenance resources. They could choose between five main types of organization (see Figure 8). The answers show that it is still most common to organize maintenance resources in a centralized maintenance function or a combination of centralized function and integrated into production. Chi-square tests indicated a significant difference across industries and across size of firms. Outsourcing and decentralized production integrated maintenance by operators, are most common in small firms. Medium-sized firms are represented by a larger proportion of companies with central maintenance departments and fewer firms with production-integrated maintenance than small and large companies (see the A ppendix).

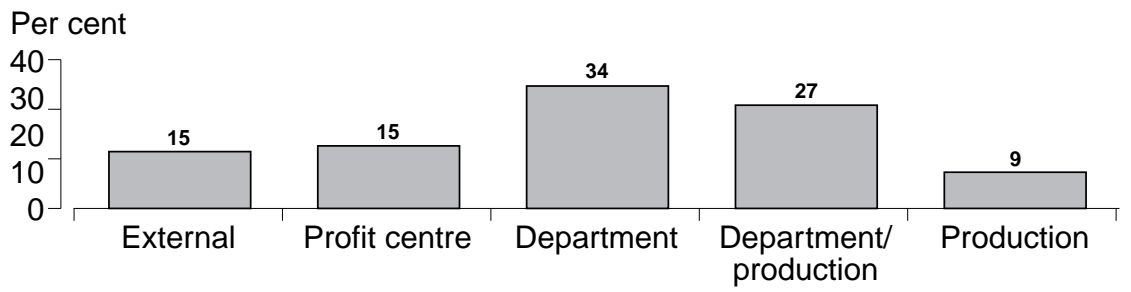

\section{Conclusions}

Maintenance management can be described as consisting of five linked components; strategy, human aspects, support mechanisms, tools and techniques, and organization. Most of the maintenance management components can probably be improved in the average Swedish manufacturing firm. It is necessary to formulate clear maintenance strategies that are linked to manufacturing and corporate strategies. Only half of the respondents of the survey had any written maintenance strategy, and all of these had not linked the maintenance strategy to production or corporate strategies. The figure is even lower in small firms and in the timber industry. Most firms with any kind of maintenance strategy involved production management to a great extent in the strategy formulation process. How ever, the commitment to maintenance issues of production management and production personnel was lower, which indicates that Swedish firms have not fully made maintenance into a companywide issue. One-third of the firms consider that maintenance has low status in their organizations and that is a great obstacle for creating strong learning organizations and working for continuous improvement.
The status of maintenance management 
JQME 3,4

246
Decentralized maintenance is becoming more important and a combination of decentralized maintenance by operators and outsourcing is common in small firms. A centralized maintenance function, however, still dominates the majority of firms. However, outsourcing and production integrated maintenance are important in small firms. A necessary condition for planning and controlling preventive and on-condition maintenance is to have a welldeveloped maintenance management information system. Only 10 per cent of the manufacturing firms in the survey considered themselves to have integrated maintenance into their management information system and very few used condition monitoring or maintenance optimization to prevent failures. However, condition monitoring was the most important technique in large process-oriented chemical and paper plants with expensivestoppage costs. The most common maintenance techniques are fixed interval inspection and corrective maintenance. A bout half of maintenance time is spent on correction and that is probably often too much.

Swedish manufacturing firms should improve their understanding of the importance of maintenance management. M ost of the necessary knowledge and technology for proper maintenance management probably exists, but too few companies have learned to use them. We consider maintenance to be the next logical progression, driven primarily by product quality, customer satisfaction considerations and long-term strategies. Research is needed in many maintenance-related areas. The present study did not focus on the relationship between various maintenance components. It is likely that the successful use of various maintenance techniques requires certain contexts, e.g. organizational design. A $n$ interesting future study would therefore be to study the links between the above discussed maintenance management components, and explain correlation the between components and also between high performance, competitive advantage and maintenance components.

\section{References}

A hlmann, H. (1984), “M aintenance effectiveness and economic models in the terotechnology concept", M aintenance M anagement International, Vol. 4, pp. 131-9

A hImann, H. (1994), T he Economic Significance of M aintenance in Industrial Enterprises, Internal Report, Department of Industrial Engineering, Lund University, Lund, Sw eden.

Bateman, J.F. (1995), "Preventive maintenance: stand al one manufacturing compared with cellular manufacturing", Industrial M anagement, Vol. No. 1, pp. 19-21.

Ben-Daya, M. and Duffuaa, S.O. (1995), "M aintenance and quality: the missing link", Journal of Quality in Maintenance Engineering, Vol. 1, No. 1, pp. 20-6.

Berger, D. (1993), "Overcoming the traditional operations/maintenance rivalry", Plant Engineering and $M$ aintenance, Vol. 16 No. 2, p. 14-16.

Blanchard, B.S. (1991), Logistics Engineering and M anagement, Prentice-Hall, Englewood Cliffs, NJ.

Buffa, E.S. (1984), M eeting the Competitive Challenge, Dow Jones-Irwing, Homew ood, IL.

Caron, H.S.J. and Ernest, H.H. Jr (1991), "The interdependency between marketing and manufacturing", Industrial M arketing M anagement, Vol. 20, pp. 223-9. 
Cochran, W.G. (1954), "Some methods for strengthening the common chi-square tests, Biometrics, Vol. 10, pp. 417-51.

Dekker, R. (1996), "A pplications of maintenance optimization models: a review and analysis", Reliability Engineering \& Systems Safety, Vol. 51 No. 2, pp. 229-40.

Deming, W.E . (1986), Out of the Crisis, MIT, Cambridge, MA .

Ericsson, J. and Dahlén, P. (1993), “Disruption reduction - an important tool in order to reach 'just in time'", Internal report, Department of Production and Materials Engineering, Lund University.

Flynn, B.B., Sakakibara, S., Schroeder, R.G., Bates, K.A . and Flynn, E.J. (1990), “E mpirical research methods in operations management", Journal of Operations Management, Vol. 9 No. 2, pp. 250-84.

Geraerds, W.J.M. (1991), "Towards a theory of maintenance", in Bertrand, J.W.N (Ed.), Onderhoud en logistiek: Op weg naar integrale beheersing (in Dutch), Samson/Nive, Eindhoven, pp. 3-44.

Hayes, R. and Pisano, G. (1994), "Beyond world-class: the new manufacturing strategy", Harvard Business Review, January-February, pp. 77-86.

Hill, T . (1990), Production/Operations M anagement, Prentice Hall, Hemel Hempstead.

Husband, T.M. (1978), M aintenance M anagement and T erotechnology, Gower Publishing, Aldershot.

Kappelman, L. and Prybutok, V. (1995), "E mpowerment, motivation, training and T QM program implementation success", Industrial M anagement, May/June, pp. 12-15.

Kelly, A . (1989), M anagement and its M anagement, Conference Communication, M onks Hill, UK.

Kovach, J. (1983), "Purchasing must push for planned maintenance", Purchasing, September, 1993, p. 29.

Maggard, B.N. and Rhyne, D.M . (1992), "Total productive maintenance: a timely integration of production and maintenance", Production and Inventory Management Journal, Vol. 33 No. 4, pp. 6-10.

Malmholt, O. (1990), “Produktionsstörningar, människan och tekniken”, UT C-meddelande nr 4, UT C, Stockholm (in Swedish).

Martin, H.H. (1997), "Contracting out maintenance and a plan for future research", Journal of Quality in M aintenance Engineering, Vol. 3, No. 2, pp. 81-90.

Miller, J.G. and Roth, A.V. (1994), "A taxonomy of manufacturing strategies", Management Sciences, Vol. 40 No. 3, pp. 285-304.

Mobley, R.K. (1990), A n Introduction to Preventive Maintenance, Plant Engineering Series, Van Nostrand Reinhold, New York.

Nakajima, S. (1988), Introduction to T PM, Productivity Press, Cambridge, MA.

Pintelon, L. (1990), "Performance reporting and decision tools for maintenance management", PhD thesis, Katholieke Universiteit Leuven, Leuven.

Pintelon, L.M . and Gelders, L.F. (1992), "Maintenance management decision making", European Journal of Operational Research, Vol. 58, pp. 301-17.

Raouf, A . and Ben-Daya, M. (1995), "Total maintenance management: a systematic approach", Journal of Quality in M aintenance Engineering, Vol. 1 No. 1, pp. 6-14.

Sherwin, D.J. (1994)., "Maintenance - an important factor forgotten in manufacturing planning systems", OR Society Conference, July 1994, Glasgow.

Skinner, W. (1969), "Manufacturing - missing link in corporate strategy”, Harvard Business Review, May-June, pp. 136-45.

Smith, A.M . (1993), Reliability-Centred M aintenance, M cGraw-Hill, New York.

Smith, C. and Knezevic, J. (1996), "A chieving quality through supportability - part I: concepts and principles", Journal of Quality in Maintenance Engineering, Vol. 2 No. 2, pp. 21-9

The status of maintenance management 
JQME 3,4
Steudel, H.J. and Desruelle, P. (1992), M anufacturing in the Nineties: How to Become a Mean, Lean, World-Class Competitor, Van Nostrand Reinhold, New York.

Thilander, M. (1992), "Some observations of operation and maintenance in two Swedish firms", Integrated M anufacturing Systems, Vol. 3 No. 2, pp. 24-31.

T ippett, D.D. and Waits, D.A . (1994), “Projects management and T QM : why aren't project managers coming on board?", Industrial Management, Vol. 36 No. 5, pp. 12-15.

Tombari, H.A . (1982), “Designing a maintenance management system”, Production and Inventory Management Journal, Vol. 23 No. 4, p. 140.

Tomlingson, P.D. (1993), Effective M aintenance - T he Key to Profitability, Van Nostrand Reinhold Company, N ew York, NY.

Tunälv, C. (1992), "Manufacturing strategy - plans and business performance”, International Journal of Operations and Production M anagement, Vol. 12 No. 3, pp. 4-24.

Vickery, S.K., Droge, C. and M arkland, R.E. (1993), "Production competence and business strategy: do they affect business performance?", Decision Sciences, Vol. 24 No. 2, pp. 435-55.

Wireman, T. (1990), World Class M aintenance M anagement, Industrial Press Inc., New York.

Yamashina, H. (1995), "Japanese manufacturing strategy and the role of total productive mintenance", Journal of Quality in M aintenance Engineering, Vol. 1 No. 1, pp. 27-38.

Young, S. (1996), "A sset management - finding the optimum for the oil and gas Industry", $M$ aintenance in Oil and Gas Conference, May, Singapore. 
A ppendix: answers grouped in industries and sizes

The status of

\begin{tabular}{|c|c|c|c|c|}
\hline \multirow[b]{2}{*}{ Industry } & \multicolumn{4}{|c|}{ Strategy } \\
\hline & $\begin{array}{c}\text { None } \\
(\%)\end{array}$ & $\begin{array}{l}\text { Oral } \\
(\%)\end{array}$ & $\begin{array}{c}\text { W ritten } \\
(\%)\end{array}$ & $\begin{array}{c}\text { No answer } \\
(\%)\end{array}$ \\
\hline Total in all industries & 23 & 28 & 41 & 1 \\
\hline $\begin{array}{l}\text { Food industry } \\
\text { Total } \\
<100 \text { employees } \\
\text { 100-500 employees } \\
\text { > } 500 \text { employees }\end{array}$ & $\begin{array}{r}19 \\
9 \\
29 \\
17\end{array}$ & $\begin{array}{l}39 \\
64 \\
14 \\
50\end{array}$ & $\begin{array}{l}39 \\
18 \\
57 \\
33\end{array}$ & $\begin{array}{l}3 \\
9 \\
0 \\
0\end{array}$ \\
\hline $\begin{array}{l}\text { T imber industry } \\
\text { Total } \\
<100 \text { employees } \\
100-500 \text { employees }\end{array}$ & $\begin{array}{l}38 \\
36 \\
40\end{array}$ & $\begin{array}{l}38 \\
43 \\
30\end{array}$ & $\begin{array}{l}24 \\
21 \\
30\end{array}$ & $\begin{array}{l}0 \\
0 \\
0\end{array}$ \\
\hline $\begin{array}{l}\text { Print/paper industry } \\
\text { Total } \\
<100 \text { employees } \\
100-500 \text { employees } \\
>500 \text { employees }\end{array}$ & $\begin{array}{r}24 \\
55 \\
18 \\
0\end{array}$ & $\begin{array}{l}21 \\
36 \\
18 \\
11\end{array}$ & $\begin{array}{r}55 \\
9 \\
64 \\
89\end{array}$ & $\begin{array}{l}0 \\
0 \\
0 \\
0\end{array}$ \\
\hline $\begin{array}{l}\text { Chemical industry } \\
\text { Total } \\
<100 \text { employees } \\
\text { 100-500 employees } \\
\text { > } 500 \text { employees }\end{array}$ & $\begin{array}{r}14 \\
13 \\
17 \\
0\end{array}$ & $\begin{array}{r}26 \\
26 \\
33 \\
0\end{array}$ & $\begin{array}{r}60 \\
61 \\
50 \\
100\end{array}$ & $\begin{array}{l}0 \\
0 \\
0 \\
0\end{array}$ \\
\hline $\begin{array}{l}\text { M echanical engineering } \\
\text { Total } \\
<100 \text { employees } \\
100-500 \text { employees } \\
\text { > } 500 \text { employees }\end{array}$ & $\begin{array}{l}28 \\
33 \\
25 \\
27\end{array}$ & $\begin{array}{l}23 \\
24 \\
19 \\
27\end{array}$ & $\begin{array}{l}49 \\
43 \\
56 \\
46\end{array}$ & $\begin{array}{l}0 \\
0 \\
0 \\
0\end{array}$ \\
\hline $\begin{array}{l}\text { Iron/steel industry } \\
\text { Total } \\
<100 \text { employees } \\
100-500 \text { employees }\end{array}$ & $\begin{array}{l}0 \\
0 \\
0\end{array}$ & $\begin{array}{l}67 \\
75 \\
60\end{array}$ & $\begin{array}{l}33 \\
25 \\
40\end{array}$ & $\begin{array}{l}0 \\
0 \\
0\end{array}$ \\
\hline
\end{tabular}

Note:

Chi-square tests identified significant differences between industries $(p<0.01)$ as well as between firms of various sizes $(p<0.05$ ). A nalysis of adjusted standardized residuals (at the level $p<0.05$ ) for each cell revealed that the paper industry had a significantly higher oral strategy, the timber industry and small firms had a significantly lower written strategy than expected

Table A I.

Formulated maintenance strategy 
$\underset{3,4}{J Q M E}$

\begin{tabular}{|c|c|c|c|c|c|c|c|}
\hline \multirow[b]{2}{*}{ Industry } & \multicolumn{6}{|c|}{ Status percentages } & \multirow[b]{2}{*}{ No answer } \\
\hline & 1 & 2 & 3 & 4 & 5 & 6 & \\
\hline Total in all industries & 3 & 9 & 20 & 29 & 27 & 11 & 1 \\
\hline $\begin{array}{l}\text { Food industry } \\
\text { Total } \\
<100 \text { employees } \\
\text { 100-500 employees } \\
\text { > } 500 \text { employees }\end{array}$ & $\begin{array}{r}8 \\
9 \\
13 \\
0\end{array}$ & $\begin{array}{l}0 \\
0 \\
0 \\
0\end{array}$ & $\begin{array}{l}19 \\
18 \\
12 \\
29\end{array}$ & $\begin{array}{l}35 \\
18 \\
50 \\
42\end{array}$ & $\begin{array}{l}27 \\
28 \\
25 \\
29\end{array}$ & $\begin{array}{r}8 \\
18 \\
0 \\
0\end{array}$ & $\begin{array}{l}3 \\
9 \\
0 \\
0\end{array}$ \\
\hline $\begin{array}{l}\text { T imber industry } \\
\text { Total } \\
<100 \text { employees } \\
100-500 \text { employees }\end{array}$ & $\begin{array}{r}4 \\
0 \\
10\end{array}$ & $\begin{array}{r}17 \\
29 \\
0\end{array}$ & $\begin{array}{l}38 \\
21 \\
60\end{array}$ & $\begin{array}{l}21 \\
29 \\
10\end{array}$ & $\begin{array}{r}13 \\
21 \\
0\end{array}$ & $\begin{array}{r}3 \\
0 \\
10\end{array}$ & $\begin{array}{r}4 \\
0 \\
10\end{array}$ \\
\hline $\begin{array}{l}\text { Print/paper industry } \\
\text { Total } \\
<100 \text { employees } \\
100-500 \text { employees } \\
>500 \text { employees }\end{array}$ & $\begin{array}{l}2 \\
5 \\
0 \\
2\end{array}$ & $\begin{array}{r}5 \\
36 \\
0 \\
2\end{array}$ & $\begin{array}{r}12 \\
24 \\
5 \\
12\end{array}$ & $\begin{array}{l}31 \\
21 \\
10 \\
25\end{array}$ & $\begin{array}{l}33 \\
12 \\
14 \\
38\end{array}$ & $\begin{array}{r}17 \\
0 \\
66 \\
19\end{array}$ & $\begin{array}{l}0 \\
2 \\
5 \\
2\end{array}$ \\
\hline $\begin{array}{l}\text { Chemical industry } \\
\text { Total } \\
<100 \text { employees } \\
100-500 \text { employees } \\
\text { > } 500 \text { employees }\end{array}$ & $\begin{array}{l}7 \\
9 \\
6 \\
0\end{array}$ & $\begin{array}{r}12 \\
13 \\
11 \\
0\end{array}$ & $\begin{array}{r}16 \\
17 \\
17 \\
0\end{array}$ & $\begin{array}{r}30 \\
30 \\
32 \\
0\end{array}$ & $\begin{array}{r}19 \\
9 \\
28 \\
50\end{array}$ & $\begin{array}{r}16 \\
22 \\
6 \\
50\end{array}$ & $\begin{array}{l}0 \\
0 \\
0 \\
0\end{array}$ \\
\hline $\begin{array}{l}\text { M echanical engineering } \\
\text { Total } \\
<100 \text { employees } \\
\text { 100-500 employees } \\
>500 \text { employees }\end{array}$ & $\begin{array}{l}2 \\
0 \\
2 \\
0\end{array}$ & $\begin{array}{r}9 \\
8 \\
10 \\
8\end{array}$ & $\begin{array}{r}24 \\
30 \\
24 \\
0\end{array}$ & $\begin{array}{l}27 \\
18 \\
33 \\
41\end{array}$ & $\begin{array}{l}31 \\
34 \\
25 \\
41\end{array}$ & $\begin{array}{r}7 \\
10 \\
6 \\
0\end{array}$ & $\begin{array}{l}0 \\
0 \\
0 \\
0\end{array}$ \\
\hline $\begin{array}{l}\text { Iron/steel industry } \\
\text { Total } \\
<100 \text { employees } \\
\text { 100-500 employees }\end{array}$ & $\begin{array}{l}0 \\
0 \\
0\end{array}$ & $\begin{array}{r}11 \\
25 \\
0\end{array}$ & $\begin{array}{r}11 \\
0 \\
20\end{array}$ & $\begin{array}{r}33 \\
0 \\
60\end{array}$ & $\begin{array}{l}33 \\
50 \\
20\end{array}$ & $\begin{array}{r}11 \\
25 \\
0\end{array}$ & $\begin{array}{l}0 \\
0 \\
0\end{array}$ \\
\hline M aintenance managers & 3 & 9 & 14 & 30 & 29 & 11 & 4 \\
\hline Production managers & 2 & 11 & 26 & 24 & 24 & 13 & 1 \\
\hline $\begin{array}{l}\text { Other management } \\
\text { (eg. CE O) }\end{array}$ & 3 & 5 & 19 & 41 & 23 & 7 & 2 \\
\hline
\end{tabular}

\section{Note:}

Table All.

Perceived status of maintenance

Kruskal-Wallis one-way A NOVA tests indicated that there are significant differences across industries $(p<0.01)$ and across various sizes $(p<0.05)$, while pairwise Mann-W hitney tests $(p<0.05)$ revealed that the food, paper and mechanical engineering industries have significantly higher status than in the timber industry, that it has significantly higher status than in the paper industry in the mechanical engineering industry, and that it has significantly lower status in small and medium sized firms than in large firms 


\begin{tabular}{|c|c|c|c|c|c|c|}
\hline \multirow[b]{2}{*}{ Industry } & \multicolumn{6}{|c|}{ Status percentages } \\
\hline & 1 & 2 & 3 & 4 & 5 & 6 \\
\hline Total in all industries & 1 & 3 & 15 & 27 & 36 & 17 \\
\hline $\begin{array}{l}\text { Food industry } \\
\text { Total } \\
<100 \text { employees } \\
\text { 100-500 employees } \\
>500 \text { employees }\end{array}$ & $\begin{array}{l}0 \\
0 \\
0 \\
0\end{array}$ & $\begin{array}{l}3 \\
0 \\
8 \\
0\end{array}$ & $\begin{array}{r}17 \\
18 \\
8 \\
33\end{array}$ & $\begin{array}{l}27 \\
27 \\
23 \\
33\end{array}$ & $\begin{array}{l}37 \\
36 \\
38 \\
33\end{array}$ & $\begin{array}{r}17 \\
18 \\
23 \\
0\end{array}$ \\
\hline $\begin{array}{l}\text { Timber industry } \\
\text { Total } \\
<100 \text { employees } \\
100-500 \text { employees }\end{array}$ & $\begin{array}{l}0 \\
0 \\
0\end{array}$ & $\begin{array}{l}0 \\
0 \\
0\end{array}$ & $\begin{array}{l}25 \\
21 \\
30\end{array}$ & $\begin{array}{l}21 \\
21 \\
20\end{array}$ & $\begin{array}{l}29 \\
36 \\
20\end{array}$ & $\begin{array}{l}21 \\
21 \\
20\end{array}$ \\
\hline $\begin{array}{l}\text { Print/paper industry } \\
\text { Total } \\
<100 \text { employees } \\
100-500 \text { employees } \\
\text { > } 500 \text { employees }\end{array}$ & $\begin{array}{l}2 \\
9 \\
0 \\
0\end{array}$ & $\begin{array}{l}2 \\
0 \\
4 \\
0\end{array}$ & $\begin{array}{r}11 \\
36 \\
4 \\
0\end{array}$ & $\begin{array}{r}27 \\
9 \\
33 \\
30\end{array}$ & $\begin{array}{l}38 \\
27 \\
38 \\
50\end{array}$ & $\begin{array}{l}18 \\
18 \\
17 \\
20\end{array}$ \\
\hline $\begin{array}{l}\text { Chemical industry } \\
\text { Total } \\
<100 \text { employees } \\
100-500 \text { employees } \\
\text { > } 500 \text { employees }\end{array}$ & $\begin{array}{l}2 \\
4 \\
0 \\
0\end{array}$ & $\begin{array}{r}7 \\
4 \\
11 \\
0\end{array}$ & $\begin{array}{r}19 \\
22 \\
17 \\
0\end{array}$ & $\begin{array}{r}21 \\
17 \\
28 \\
0\end{array}$ & $\begin{array}{r}40 \\
30 \\
44 \\
100\end{array}$ & $\begin{array}{r}12 \\
22 \\
0 \\
0\end{array}$ \\
\hline $\begin{array}{l}\text { M echanical engineering } \\
\text { Total } \\
<100 \text { employees } \\
100-500 \text { employees } \\
>500 \text { employees }\end{array}$ & $\begin{array}{l}0 \\
0 \\
0 \\
0\end{array}$ & $\begin{array}{l}3 \\
2 \\
4 \\
7\end{array}$ & $\begin{array}{r}12 \\
10 \\
17 \\
7\end{array}$ & $\begin{array}{l}29 \\
27 \\
37 \\
13\end{array}$ & $\begin{array}{l}36 \\
44 \\
25 \\
40\end{array}$ & $\begin{array}{l}16 \\
16 \\
13 \\
27\end{array}$ \\
\hline $\begin{array}{l}\text { Iron/steel industry } \\
\text { Total } \\
<100 \text { employees } \\
100-500 \text { employees }\end{array}$ & $\begin{array}{l}0 \\
0 \\
0\end{array}$ & $\begin{array}{l}0 \\
0 \\
0\end{array}$ & $\begin{array}{r}11 \\
25 \\
0\end{array}$ & $\begin{array}{l}33 \\
25 \\
40\end{array}$ & $\begin{array}{r}11 \\
25 \\
0\end{array}$ & $\begin{array}{l}44 \\
25 \\
60\end{array}$ \\
\hline
\end{tabular}

\section{Note:}

Kruskal-Wallis one-way A NOVA tests identified no significant difference $(p<0.05)$ across industries or sizes

Table AIII.

Commitment of production management 


\begin{tabular}{|c|c|c|c|c|c|c|c|}
\hline \multirow{2}{*}{$\begin{array}{l}\int_{3,4} \mathrm{M} E \\
3 .\end{array}$} & \multirow[b]{2}{*}{ Industry } & \multicolumn{6}{|c|}{ Status percentages } \\
\hline & & 1 & 2 & 3 & 4 & 5 & 6 \\
\hline \multirow{27}{*}{252} & Total in all industries & 2 & 13 & 28 & 33 & 16 & 5 \\
\hline & Food industry & 3 & 10 & 17 & 30 & 7 & 3 \\
\hline & $<100$ employees & 0 & 18 & 36 & 27 & 9 & 9 \\
\hline & 100-500 employees & 8 & 0 & 46 & 38 & 8 & 0 \\
\hline & > 500 employees & 0 & 17 & 67 & 17 & 0 & 0 \\
\hline & T imber industry & & & & & & \\
\hline & Total & 4 & 13 & 21 & 29 & 13 & 8 \\
\hline & $<100$ employees & 0 & 14 & 29 & 36 & 7 & 7 \\
\hline & 100-500 employees & 10 & 10 & 10 & 20 & 20 & 10 \\
\hline & Print/paper industry & & & & & & \\
\hline & Total & 2 & 11 & 47 & 36 & 11 & 0 \\
\hline & $<100$ employees & 0 & 9 & 27 & 36 & 27 & 0 \\
\hline & 100-500 employees & 0 & 4 & 58 & 25 & 8 & 0 \\
\hline & > 500 employees & 0 & 20 & 30 & 20 & 30 & 0 \\
\hline & Chemical industry & & & & & & \\
\hline & Total & 7 & 21 & 28 & 28 & 14 & 2 \\
\hline & 100-500 employees & $\begin{array}{r}4 \\
11\end{array}$ & $\begin{array}{l}11 \\
28\end{array}$ & 28 & 22 & $\begin{array}{l}11 \\
11\end{array}$ & $\begin{array}{l}4 \\
0\end{array}$ \\
\hline & $>500$ employees & 0 & 0 & 50 & 50 & 0 & 0 \\
\hline & M echanical engineering & & & & & & \\
\hline & Total & 1 & 10 & 24 & 39 & 18 & 5 \\
\hline & $<100$ employees & 2 & 11 & 19 & 35 & 25 & 0 \\
\hline & 100-500 employees & 0 & 10 & 31 & 40 & 10 & 6 \\
\hline & > 500 employees & 0 & 7 & 20 & 53 & 13 & 0 \\
\hline & Iron/steel industry & & & & & & \\
\hline & Total & 0 & 33 & 22 & 22 & 22 & 0 \\
\hline & < 100 employees & 0 & 50 & 25 & 0 & 25 & 0 \\
\hline & 100-500 employees & 0 & 20 & 20 & 40 & 20 & 0 \\
\hline
\end{tabular}

Table A IV.

Commitment of production personnel

\section{Note:}

Kruskal-Wallis one-way A NOVA tests indicate significant difference $(p<0.05)$ across industries, but not across sizes. Pairwise M ann-W hitney tests $(p<0.05)$ revealed that the commitment in the food and chemistry industries are significantly lower than in the mechanical engineering industry 


\begin{tabular}{|c|c|c|c|c|c|c|c|}
\hline \multirow[b]{2}{*}{ Industry } & \multicolumn{6}{|c|}{ Status percentages } & \multirow{2}{*}{$\begin{array}{l}\text { The status of } \\
\text { maintenance } \\
\text { management }\end{array}$} \\
\hline & 1 & 2 & 3 & 4 & 5 & 6 & \\
\hline Total in all industries & 1 & 1 & 5 & 13 & 38 & 42 & \multirow[b]{2}{*}{253} \\
\hline $\begin{array}{l}\text { Food industry } \\
\text { Total } \\
<100 \text { employees } \\
100-500 \text { employees } \\
>500 \text { employees }\end{array}$ & $\begin{array}{l}0 \\
0 \\
0 \\
0\end{array}$ & $\begin{array}{l}0 \\
0 \\
0 \\
0\end{array}$ & $\begin{array}{r}8 \\
0 \\
11 \\
20\end{array}$ & $\begin{array}{l}17 \\
20 \\
11 \\
20\end{array}$ & $\begin{array}{l}33 \\
40 \\
11 \\
60\end{array}$ & $\begin{array}{r}42 \\
40 \\
67 \\
0\end{array}$ & \\
\hline $\begin{array}{l}\text { Timber industry } \\
\text { Total } \\
<100 \text { employees } \\
100-500 \text { employees }\end{array}$ & $\begin{array}{l}0 \\
0 \\
0\end{array}$ & $\begin{array}{l}0 \\
0 \\
0\end{array}$ & $\begin{array}{r}7 \\
0 \\
17\end{array}$ & $\begin{array}{l}14 \\
13 \\
17\end{array}$ & $\begin{array}{l}36 \\
25 \\
50\end{array}$ & $\begin{array}{l}43 \\
63 \\
17\end{array}$ & \\
\hline $\begin{array}{l}\text { Print/paper industry } \\
\text { Total } \\
<100 \text { employees } \\
100-500 \text { employees } \\
>500 \text { employees }\end{array}$ & $\begin{array}{l}3 \\
0 \\
5 \\
0\end{array}$ & $\begin{array}{l}0 \\
0 \\
0 \\
0\end{array}$ & $\begin{array}{l}0 \\
0 \\
0 \\
0\end{array}$ & $\begin{array}{r}17 \\
0 \\
10 \\
40\end{array}$ & $\begin{array}{l}44 \\
67 \\
40 \\
40\end{array}$ & $\begin{array}{l}36 \\
33 \\
45 \\
20\end{array}$ & \\
\hline $\begin{array}{l}\text { Chemical industry } \\
\text { Total } \\
<100 \text { employees } \\
100-500 \text { employees } \\
>500 \text { employees }\end{array}$ & $\begin{array}{r}5 \\
0 \\
13 \\
0\end{array}$ & $\begin{array}{l}0 \\
0 \\
0 \\
0\end{array}$ & $\begin{array}{l}5 \\
5 \\
7 \\
0\end{array}$ & $\begin{array}{r}14 \\
25 \\
0 \\
0\end{array}$ & $\begin{array}{l}35 \\
20 \\
53 \\
50\end{array}$ & $\begin{array}{l}41 \\
50 \\
27 \\
50\end{array}$ & \\
\hline $\begin{array}{l}\text { M echanical engineering } \\
\text { Total } \\
<100 \text { employees } \\
\text { 100-500 employees } \\
>500 \text { employees }\end{array}$ & $\begin{array}{l}0 \\
0 \\
0 \\
0\end{array}$ & $\begin{array}{l}2 \\
0 \\
3 \\
9\end{array}$ & $\begin{array}{r}6 \\
2 \\
10 \\
9\end{array}$ & $\begin{array}{r}8 \\
7 \\
5 \\
27\end{array}$ & $\begin{array}{l}40 \\
48 \\
35 \\
27\end{array}$ & $\begin{array}{l}43 \\
43 \\
48 \\
27\end{array}$ & \\
\hline $\begin{array}{l}\text { Iron/steel industry } \\
\text { Total } \\
<100 \text { employees } \\
\text { 100-500 employees }\end{array}$ & $\begin{array}{l}0 \\
0 \\
0\end{array}$ & $\begin{array}{l}0 \\
0 \\
0\end{array}$ & $\begin{array}{l}0 \\
0 \\
0\end{array}$ & $\begin{array}{r}22 \\
50 \\
0\end{array}$ & $\begin{array}{l}22 \\
25 \\
20\end{array}$ & $\begin{array}{l}56 \\
25 \\
80\end{array}$ & \\
\hline \multicolumn{7}{|c|}{$\begin{array}{l}\text { Note: } \\
\text { Kruskal-Wallis one-way A NOVA tests identified significant difference }(p<0.05) \text { across sizes } \\
\text { offirms, but not across industries. Pairwise Mann-W hitney tests }(p<0.05) \text { revealed that } \\
\text { production management in small and medium sized firms participate to a significantly higher } \\
\text { level than in large firms }\end{array}$} & $\begin{array}{r}\text { Table AV. } \\
\text { Participation of } \\
\text { production management }\end{array}$ \\
\hline
\end{tabular}




\begin{tabular}{|c|c|c|c|c|c|c|c|}
\hline \multirow{2}{*}{$\begin{array}{l}\text { JQME } \\
3,4\end{array}$} & \multirow[b]{2}{*}{ Industry } & \multicolumn{6}{|c|}{ Status percentages } \\
\hline & & 1 & 2 & 3 & 4 & 5 & 6 \\
\hline & Total in all industries & 6 & 017 & 26 & 27 & 14 & 9 \\
\hline \multirow{24}{*}{254} & Food industry & & & & & & \\
\hline & $\begin{array}{l}\text { Total } \\
<100 \text { emplovees }\end{array}$ & 0 & $\begin{array}{l}29 \\
20\end{array}$ & $\begin{array}{l}29 \\
30\end{array}$ & $\begin{array}{l}29 \\
30\end{array}$ & 10 & $\begin{array}{r}4 \\
10\end{array}$ \\
\hline & 100-500 employees & 0 & 22 & 22 & 44 & 11 & 0 \\
\hline & > 500 employees & 0 & 60 & 40 & 0 & 0 & 0 \\
\hline & T imber industry & & & & & & \\
\hline & $\begin{array}{l}\text { Total } \\
<100 \text { emplovees }\end{array}$ & $\begin{array}{l}0 \\
0\end{array}$ & $\begin{array}{l}14 \\
13\end{array}$ & $\begin{array}{l}29 \\
25\end{array}$ & $\begin{array}{l}43 \\
38\end{array}$ & $\begin{array}{l}0 \\
0\end{array}$ & $\begin{array}{r}7 \\
13\end{array}$ \\
\hline & $100-500$ employees & 0 & $\begin{array}{l}13 \\
17\end{array}$ & 33 & $\begin{array}{l}30 \\
50\end{array}$ & 0 & $\begin{array}{r}13 \\
0\end{array}$ \\
\hline & Print/paper industry & & & & & & \\
\hline & & 11 & $\begin{array}{r}11 \\
0\end{array}$ & 25 & $\begin{array}{l}36 \\
50\end{array}$ & $\begin{array}{r}8 \\
17\end{array}$ & $\begin{array}{l}8 \\
0\end{array}$ \\
\hline & $\begin{array}{l}\text { 100 employees } \\
100-500 \text { employees }\end{array}$ & 10 & 0 & 30 & 35 & 10 & 15 \\
\hline & > 500 employees & 11 & 11 & 26 & 34 & 9 & 9 \\
\hline & Chemical industry & & & & & & \\
\hline & Total & 6 & 28 & 28 & 14 & 11 & 14 \\
\hline & < 100 employees & 0 & $\begin{array}{l}21 \\
33\end{array}$ & 32 & 5 & 16 & 26 \\
\hline & $\begin{array}{l}100-500 \text { employees } \\
\text { > } 500 \text { employees }\end{array}$ & $\begin{array}{r}13 \\
0\end{array}$ & 50 & $\begin{array}{r}21 \\
0\end{array}$ & $\begin{array}{l}20 \\
50\end{array}$ & $\begin{array}{l}7 \\
0\end{array}$ & $\begin{array}{l}0 \\
0\end{array}$ \\
\hline & M echanical engineering & & & & & & \\
\hline & Total & 5 & 13 & 26 & 24 & 22 & 8 \\
\hline & $<100$ employees & 0 & 9 & 26 & 21 & 28 & 14 \\
\hline & 100-500 employees & $\begin{array}{r}8 \\
18\end{array}$ & 15 & 28 & 33 & $\begin{array}{l}15 \\
18\end{array}$ & $\begin{array}{l}3 \\
9\end{array}$ \\
\hline & > 500 employees & 18 & 18 & 21 & 9 & 18 & \\
\hline & Iron/steel industry & & & & & & \\
\hline & Total & 11 & 22 & 11 & 33 & 11 & 11 \\
\hline & $<100$ employees & 0 & 0 & 0 & 75 & 0 & 25 \\
\hline & 100-500 employees & 20 & 40 & 20 & 0 & 20 & 0 \\
\hline
\end{tabular}

Table AVI.

Participation of direct production personnel
Note:

Kruskal-Wallis one-way ANOVA tests identified significant difference across sizes of firms, but not across industries. Pairwise M ann-W hitney tests $(p<0.05)$ revealed that production personnel in small firms participate to a significantly higher level than in medium and large sized firms 


\begin{tabular}{|c|c|c|c|c|c|}
\hline Industry & Manual & Special & Standard & Integrated & $\begin{array}{l}\text { I he status of } \\
\text { maintenance }\end{array}$ \\
\hline Total in all industries & 64 & 15 & 12 & 9 & management \\
\hline $\begin{array}{l}\text { Food industry } \\
\text { Total } \\
\text { < } 100 \text { employees } \\
100-500 \text { employees } \\
>500 \text { employees }\end{array}$ & $\begin{array}{l}60 \\
82 \\
62 \\
17\end{array}$ & $\begin{array}{r}23 \\
9 \\
22 \\
50\end{array}$ & $\begin{array}{r}10 \\
0 \\
8 \\
33\end{array}$ & $\begin{array}{l}7 \\
9 \\
8 \\
0\end{array}$ & 255 \\
\hline $\begin{array}{l}\text { Timber industry } \\
\text { Total } \\
<100 \text { employees } \\
\text { 100-500 employees }\end{array}$ & $\begin{array}{l}84 \\
93 \\
70\end{array}$ & $\begin{array}{r}4 \\
0 \\
10\end{array}$ & $\begin{array}{r}4 \\
0 \\
10\end{array}$ & $\begin{array}{r}8 \\
7 \\
10\end{array}$ & \\
\hline $\begin{array}{l}\text { Print/paper industry } \\
\text { Total } \\
<100 \text { employees } \\
100-500 \text { employees } \\
\text { > } 500 \text { employees }\end{array}$ & $\begin{array}{r}53 \\
100 \\
50 \\
50\end{array}$ & $\begin{array}{r}14 \\
0 \\
23 \\
20\end{array}$ & $\begin{array}{r}12 \\
0 \\
9 \\
10\end{array}$ & $\begin{array}{r}21 \\
0 \\
18 \\
20\end{array}$ & \\
\hline $\begin{array}{l}\text { Chemical industry } \\
\text { Total } \\
<100 \text { employees } \\
100-500 \text { employees } \\
>500 \text { employees }\end{array}$ & $\begin{array}{r}72 \\
82 \\
67 \\
0\end{array}$ & $\begin{array}{r}9 \\
5 \\
11 \\
50\end{array}$ & $\begin{array}{r}12 \\
8 \\
17 \\
0\end{array}$ & $\begin{array}{r}7 \\
5 \\
5 \\
50\end{array}$ & \\
\hline $\begin{array}{l}\text { M echanical engineering } \\
\text { Total } \\
<100 \text { employees } \\
100-500 \text { employees } \\
>500 \text { employees }\end{array}$ & $\begin{array}{l}62 \\
75 \\
57 \\
27\end{array}$ & $\begin{array}{r}16 \\
8 \\
22 \\
36\end{array}$ & $\begin{array}{l}13 \\
10 \\
14 \\
19\end{array}$ & $\begin{array}{r}9 \\
7 \\
7 \\
18\end{array}$ & \\
\hline $\begin{array}{l}\text { Iron/steel industry } \\
\text { Total } \\
<100 \text { employees } \\
100-500 \text { employees }\end{array}$ & $\begin{array}{r}67 \\
100 \\
40\end{array}$ & $\begin{array}{r}11 \\
0 \\
20\end{array}$ & $\begin{array}{r}22 \\
0 \\
40\end{array}$ & $\begin{array}{l}0 \\
0 \\
0\end{array}$ & \\
\hline \multicolumn{6}{|c|}{$\begin{array}{l}\text { Note: } \\
\text { Chi-square tests could not identify any significant difference across industries, but across sizes } \\
(p<0.01) \text {. A nalysis of adjusted standardized residuals (at the level } p<0.05 \text { ) for each cell revealed } \\
\text { that small firms used manual systems significantly more frequently and special, standard and } \\
\text { integrated systems significantly less frequently than large firms }\end{array}$} \\
\hline
\end{tabular}


$\underset{3,4}{J Q M E}$

Industry External $\quad \begin{gathered}\text { Profit } \\ \text { centred }\end{gathered}$ Department $\begin{gathered}\text { Department/ } \\ \text { production }\end{gathered}$ Production

\begin{tabular}{llllll}
\hline Total in all industries & 15 & 15 & 34 & 27
\end{tabular}

\section{6}

Food industry

Total

$<100$ employees

100-500 employees

$>500$ employees

320

Timber industry

Total

$<100$ employees

100-500 employees

9
0

0

$20 \quad 67$

67

73

9
23

33

62

67

9

Print/paper industry

Total

$<100$ employees

100-500 employees

$>500$ employees

$\begin{array}{rr}13 & 21 \\ 7 & 2 \\ 20 & 20\end{array}$

$21 \quad 29$

$21 \quad 29$

$20 \quad 30$

33

$30 \quad 30$

$\begin{array}{rl}10 & 0 \\ 9 & 0 \\ 15 & 0 \\ 0 & 0\end{array}$

Chemical industry

Total

$<100$ employees

100-500 employees

> 500 employees

$5 \quad 49$

49
27

27
62

62
44

$\begin{array}{ll}33 & 4 \\ 36 & 7 \\ 30 & 0\end{array}$

$M$ echanical engineering

Total

$<100$ employees

100-500 employees

$>500$ employees

Iron/steel industry

Total

$<100$ employees

100-500 employees

0
0
0
0

4
0

$\begin{array}{rr}34 & 12 \\ 36 & 27 \\ 24 & 10 \\ 56 & 0\end{array}$

\section{Note:}

Chi-square tests $(p<0.01)$ identified significant variations across industries and sizes. A nalysis of adjusted standardized residuals (at the level $p<0.05$ ) for each cell revealed that the food industry had significantly larger proportion of external organization and significantly smaller proportion of maintenance department than expected, that the paper industry had significantly smaller proportion of external organization than expected, that the mechanical engineering industry had significantly larger proportion of external maintenance and significantly smaller proportion of maintenance departments than expected, that small firms had significantly larger proportion of external maintenance and production integrated maintenance but significantly smaller proportion of maintenance department than expected, that medium sized firms had

Table AVIII.

Maintenance organization significantly higher proportion of maintenance department and significantly lower proportion of production integrated maintenance than expected, and that large firms had significantly lower proportion of external maintenance than expected 


\begin{tabular}{|c|c|c|c|c|}
\hline Industry & Planning & Preventive & Corrective & $\begin{array}{l}\text { The status of } \\
\text { maintenance }\end{array}$ \\
\hline Total in all industries & 10 & 41 & 49 & management \\
\hline $\begin{array}{l}\text { Food industry } \\
\text { Total } \\
<100 \text { employees } \\
100-500 \text { employees } \\
>500 \text { employees }\end{array}$ & $\begin{array}{r}8 \\
9 \\
10 \\
2\end{array}$ & $\begin{array}{l}46 \\
52 \\
47 \\
30\end{array}$ & $\begin{array}{l}46 \\
39 \\
43 \\
68\end{array}$ & 257 \\
\hline $\begin{array}{l}\text { T imber industry } \\
\text { Total } \\
<100 \text { employees } \\
\text { 100-500 employees }\end{array}$ & $\begin{array}{r}10 \\
10 \\
9\end{array}$ & $\begin{array}{l}33 \\
33 \\
33\end{array}$ & $\begin{array}{l}57 \\
57 \\
58\end{array}$ & \\
\hline $\begin{array}{l}\text { Print/paper industry } \\
\text { Total } \\
<100 \text { employees } \\
100-500 \text { employees } \\
\text { > } 500 \text { employees }\end{array}$ & $\begin{array}{r}9 \\
11 \\
7 \\
12\end{array}$ & $\begin{array}{l}45 \\
41 \\
47 \\
45\end{array}$ & $\begin{array}{l}46 \\
48 \\
46 \\
43\end{array}$ & \\
\hline $\begin{array}{l}\text { Chemical industry } \\
\text { Total } \\
<100 \text { employees } \\
100-500 \text { employees } \\
\text { > } 500 \text { employees }\end{array}$ & $\begin{array}{r}10 \\
10 \\
10 \\
8\end{array}$ & $\begin{array}{l}41 \\
44 \\
38 \\
38\end{array}$ & $\begin{array}{l}49 \\
46 \\
52 \\
54\end{array}$ & \\
\hline $\begin{array}{l}\text { M echanical engineering } \\
\text { Total } \\
<100 \text { employees } \\
100-500 \text { employees } \\
>500 \text { employees }\end{array}$ & $\begin{array}{r}9 \\
10 \\
9 \\
4\end{array}$ & $\begin{array}{l}42 \\
43 \\
42 \\
39\end{array}$ & $\begin{array}{l}49 \\
47 \\
49 \\
57\end{array}$ & \\
\hline $\begin{array}{l}\text { Iron/steel industry } \\
\text { Total } \\
<100 \text { employees } \\
\text { 100-500 employees }\end{array}$ & $\begin{array}{l}10 \\
16 \\
16\end{array}$ & $\begin{array}{l}34 \\
22 \\
22\end{array}$ & $\begin{array}{l}56 \\
62 \\
62\end{array}$ & \\
\hline \multicolumn{4}{|c|}{$\begin{array}{l}\text { Note: } \\
\text { F-test (one-way A NOVA) indicated significant differences across firm sizes regarding planning. } \\
\text { Pairwise Scheffe's tests }(p<0.05) \text { revealed that small firms spend a significantly larger proportion } \\
\text { of time on strategic planning than large firms }\end{array}$} & $\begin{array}{r}\text { Table A IX. } \\
\text { Planning, preventative } \\
\text { and corrective } \\
\text { maintenance }\end{array}$ \\
\hline
\end{tabular}


$\underset{3,4}{J Q M E}$

$\begin{array}{lllll} & \text { Condition Human Maintenance Annual } & \text { Other } & \\ \text { Industry } & \text { monitoring senses optimization service } & \text { preventive Corrective }\end{array}$

\begin{tabular}{lllllll}
\hline Total in all industries & 5 & 18 & 3 & 13 & 32 & 29
\end{tabular}

Food industry

Total

$<100$ employees

100-500 employees

$>500$ employees

$\begin{array}{rrr}6 & 25 & 6 \\ 0 & 37 & 3 \\ 9 & 19 & 12 \\ 12 & 13 & 0\end{array}$

29

T imber industry

Total

$<100$ employees

100-500 employees

$\begin{array}{ll}3 & 24 \\ 2 & 32\end{array}$

$5 \quad 13$

0
0
0

10
12
13
0

$\begin{array}{ll}39 & 14 \\ 33 & 15 \\ 35 & 12 \\ 56 & 19\end{array}$

Print/paper industry

Total

$<100$ employees

100-500 employees

$>500$ employees

$\begin{array}{rr}10 & 21 \\ 0 & 21\end{array}$

$0 \quad 21$

$5 \quad 17$

Chemical industry

Total

$<100$ employees

100-500 employees

$>500$ employees

$38 \quad 31$

2
0
2
8

$\begin{array}{rll}13 & 18 & 42 \\ 18 & 11 & 37 \\ 6 & 28 & 48\end{array}$

$M$ echanical engineering

Total

$<100$ employees

100-500 employees

> 500 employees

$\begin{array}{rc}9 & 14 \\ 9 & 12 \\ 4 & 18 \\ 60 & 0\end{array}$

9
13
11
0

$\begin{array}{rr}32 & 26 \\ 34 & 32 \\ 33 & 32 \\ 23 & 0\end{array}$

Iron/steel industry

Total

$<100$ employees

100-500 employees

$\begin{array}{rcrrrr}3 & 15 & 3 & 18 & 31 & 30 \\ 2 & 16 & 4 & 23 & 26 & 29 \\ 4 & 15 & 2 & 13 & 36 & 30 \\ 7 & 7 & 7 & 6 & 41 & 32\end{array}$

\section{Note:}

Kruskal-Wallis one-way ANOVA tests indicated no significant difference across industries, but across firm sizes regarding condition monitoring $(p<0.05)$ and annual service $(p<0.05)$. Pairwise M ann-W hitney tests $(p<0.05$ ) revealed that large firms use condition monitoring

Table AX. techniques to a significantly larger extent than small and medium sized firms, and annual service 